\title{
Contribution of Non-Timber Forest Products in Rural Communities' Livelihoods around Chilimo Forest, West Shewa, Ethiopia
}

\author{
Gadisa Demie \\ Department of Forestry, College of Agriculture and Veterinary Science, Ambo University, P.O.Box 19, Ambo, \\ Ethiopia
}

\begin{abstract}
In recent decades there has been growing interest in the contribution of non-timber forest products (NTFPs) for rural people livelihood improvement and poverty alleviation. However, as to the knowledge of the present researcher, limited studies have been done to analyze the role of non-timber forest products for rural livelihood diversification. Therefore, this study was conducted to identify main NTFPs used by local communities around Chilimo Forest. Furthermore, the study aimed to determine socioeconomic factors influencing collection of NTFPs in the study area. Multistage sampling techniques were used for the study. Data for the study was generated through household survey comprising of 313 respondents selected through simple random technique and substantiated by in-depth interviews of key informants, focus group discussion and field observation. Descriptive statistics and linear regression analysis were used to analyze and summarize data. The results revealed that, crop production, animal husbandry, non timber forest product and non-farm activities were the major livelihood strategies in the study area. On average, income from NTFPs accounted for $29.34 \%$ of total household income. The commonly collected NTFPs were firewood, charcoal, grasses, herbal medicine and honey. The study found that, households derived a significant portion of their income from the collection of NTFPs; however income derived from the collection of NTFPs significantly influenced with gender, family size and wealth status while age, education, marital status and distance from forest were found to have no significance association with income sourced from NTFPs. This study also revealed that, enrichment planting of the most utilized tree species, participatory forest management and setting of harvesting levels and cycles in Chilimo forest reduce impacts on plant species that are in high demand by local communities. The findings suggest that NTFPs play an important role in supporting livelihoods, and therefore provide an important safety net for households throughout the year particularly during periods of hardship. Therefore the current research would be useful in preparing an ecologically viable policy for the subsistence of forest dwellers and better management of the forest resources in Chilimo forest.
\end{abstract}

Keywords: Chilimo forest, non timber forest product, rural community socio-economic factors

DOI: $10.7176 / \mathrm{JNSR} / 9-22-04$

Publication date: November $30^{\text {th }} 2019$

\section{Introduction}

Non-timber forest products (NTFPs) encompass a wide variety of items derived from the forest other than timber extracted from forests, woodlands and trees outside forests for human use (CIFOR, 2011). It include bamboo, seeds, leaves, rattan, raffia, and other fibers contribute immensely to the subsistence, daily life and welfare of people all over the world especially in rural economies of the developing world (Mahaptara and Mitchell, 2011; Aiyeloja and Ajewole, 2006). Non-timber forest products (NTFPs) become important source of livelihood to a large population across world, mostly for forest-fringe and rural the people by providing food, remedy, employment, income, and reducing poverty (Endamana et al., 2016; Pandey et al., 2016; Suleiman et al., 2017). It is estimated that about 1.6 billion people globally are substantially rely on NTFPs for livelihood sustenance (Bwalya, 2013). In developing countries more than $80 \%$ of the population uses NTFPs to meet some of their health and nutritional needs (FAO, 1996; 2008). Similarly, a large proportion of rural population in Africa and Asia extract diverse range of non-timber forest products (NTFPs) for subsistence and income generation (Endamana et al., 2016). About 300 million people in tropical forests, earn their livelihood through NTFPs use (Mulenga et al., 2011). In Africa continent, with a forest cover of $21 \%$, NTFPs also continue to be an important source of household nutrition, health and income (FAO, 2011). The NTFPs are therefore a safety net for forest-dependent rural communities during periods of hardship and hence are a flagship of their sociocultural and economic growth (Endamana et al., 2016; Ojea et al., 2016; Suleiman et al., 2017).

Ethiopia is also struggling with many of problems, including deepening poverty situations in our country; especially the forest-dependent rural communities. These rural communities are mostly located in remote areas where most of the social services are limited. As a result, these rural communities find themselves heavily depend on the natural forest within their proximity oftentimes. Therefore, natural forests, particularly the non-timber forest products (NTFPs) have been established as an essential source of livelihood for the majority of forest dependent communities among others. In Ethiopia, more than 65 percent of the households who were involved in NTFP's 
did earn more than one thousand Birr (about USD 100) a year from the production of NTFP's alone (Gardei, 2006). It has been estimated that NTFPs provide up to USD 2.3 billion per annum in national economies of Ethiopia (Worku, 2014).

Like many other Ethiopian, people around Chilimo forest rely on NTFPs for their subsistence and income generation. The government is promoting the NTFPs-based activities as a developmental strategy for uplifting and empowering the forest-based communities through Joint Forest Management (Pandey et al., 2011). Moreover, the government empowered local people to participate in planning, designing, implementing, managing and benefit sharing of forest resources under the participatory forest management program in Chilimo forest.

In spite of the importance of NTFP and their contribution to rural livelihood in Ethiopia, and Chilimo forest in particular, many problems persist in the truthful estimation of NTFPs as source of income for the livelihoods improvement. The role of NTFPs in livelihood improvement is not well studied due to the absence of a systematic and rigorous data collection system at national level in several developing countries (FAO, 2012). Nowadays, the professional efforts to evaluate the economic potential of NTFPs are systematically attempted since globally NTFP as an essential medium of economic and sustainable development is seriously considered (Angelsen et al., 2014; Wunder et al., 2014). Understanding the socioeconomic contribution of NTFPs to rural livelihoods necessitates identification of factors that affect dependency levels on NTFPs by the local people. Appreciation of forest income dependence is instrumental for guiding plans of forest use at both local and national levels. In view of this, the study was undertaken to investigate the economic contribution of NTFPs to the rural household income and to assess socioeconomic characteristics that determine household dependence on income from NTFPs around Chilimo forest.

\section{Materials and Methods}

\subsection{Description of the study area}

The study was conducted in Chilimo forest, which is one of the oldest PFM intervention sites in Ethiopia, located in West Shewa Ethiopia (Figure 1). Chilimo Forest represents the remnants of the dry Afro-montane forests in the central plateau of Ethiopia. The main species in the canopy layers are Junipers procera, Podocarpus falcatus, Prunus africana, Olea europaea subspecies cuspidata, Hagenia abyssinica, Apodytes dimidiata, Ficus spp., Erythrina brucei, and Croton macrosytachus. This forest is also home to some 150 bird species, of which five are Ethiopian endemics and many more are Afro Tropical Highlands'biome species. Chilimo forest is characterized by the presence of Juniperus procera (Tsid), Podocarpus falcatus (Zigba), Prunus africana (Tikur Enchet) Olea europaea subspecies cuspidata, (Weyra), Hagenia abyssinica, (Kosso) and Apodytes dimidiata, Ficus spp. (Shola). This makes it the main source of indigenous tree seeds for the central highlands. According to wildlife surveys undertaken in 1982, there are about 180 specious of birds and 21 mammals in this forest reserve. A number of rivers including, Awash River, start from within the Chilimo forest. The vegetation throughout this area has been subject to human interference for over 2,000 years (longer than in any other East African country), and the rate of deforestation has been extremely high, with significant changes in forest cover observed even since the 1970s (Agrawal and Ostrom, 2001). The forest is Montane-mixed broadleaf-coniferous, although conifers predominate. Historically, this entire upland area is thought to have been covered by Juniperus Podocarpus forest, but most of the forest has been cleared for agriculture, and this encroachment continued. Selective cutting of trees for commercial use stopped about 1973, but illegal cutting by the local people for fuel wood sale continued. The forest is important to local people for grazing, fodder, commercial and subsistence fuel wood extraction, herbal medicine for humans and animals, farm implements, construction poles and timber and occasionally non timber forest products (Alden, 2011). A few shrub species dominate, such as Myrsine africana, with others like Maytenus arbutifolia and Rubus apetalus abundant indicators of forest disturbance. Small patches of plantation forests, initiated by the forestry department of the state in 1976, are present within the forested lands. Indigenous and exotic species are used; the main exotic species are Eucalyptus saligna, E. camaldulensis, Pinus patula and Cupressus lusitanica, with indigenous ones including Juniperus procera, Hagenia abyssinica and Podocarpus falcatus. In response to failure of previous "fences and fines" approach, the FARM-Africa's Chilimo Participatory Forest Management phase I and II Projects were operational from 1996-2006. Also the 2003 regional legislation on forest management allows for devolution of management power and handover ownership status to local people or community based organizations (CBOs). PFM approach was introduced in 1996 as a strategy to arrest forest degradation and to meet the livelihood needs of the local community (Alemayehu and Wiersum, 2006). Transferring the ownership of the forest was made in 2004 when the district cooperative promotion bureau legalized the by-laws of forest cooperatives, clarifying the responsibilities. The FCs and government signed a contractual agreement to manage the forest in jointly base and share both the responsibilities of and benefits from establishing and maintaining PFM. Currently, there are 10 legally registered Forest Cooperatives (FCs) and two Forest User Groups (FUGs). From these ten forest cooperatives the eight were formed one forestry cooperative union-Chilimo forest cooperative union (Arts and Buizerm, 2009). 


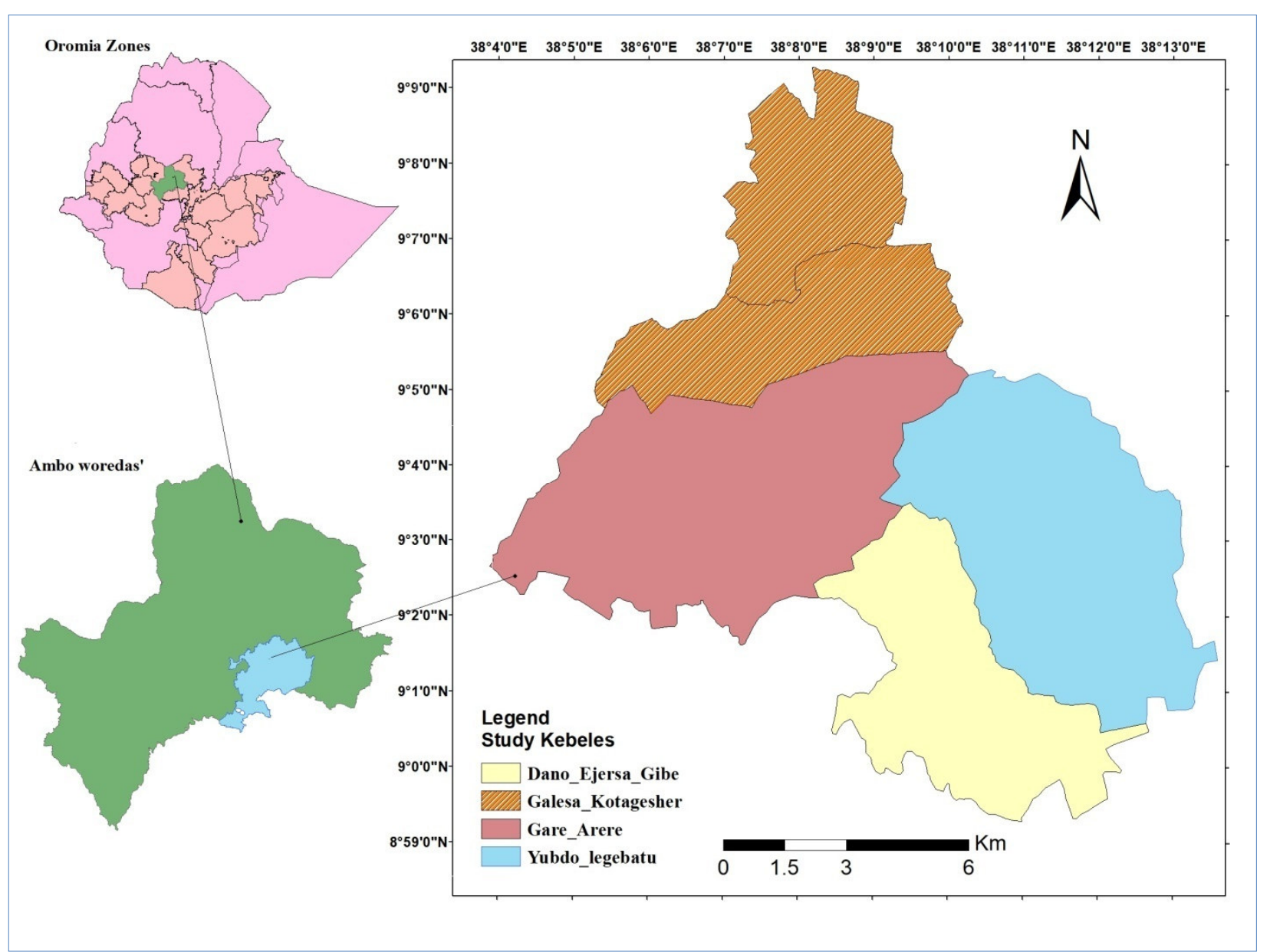

Figure 1: Map of study areas

\subsection{Sample size and sampling techniques}

Multi-stage sampling technique was used to select the sample households for the study. The Chilimo forest extends over parts of seven kebeles of the Dendi district. Out of those, four kebeles were purposively selected based on the existence of large portions of the reserved forest in their territories, as well as the high number of forest-dependent communities in the selected kebeles. Accordingly, Dano Ejersa Gibe, Galessa Kotagesher, Gare Arere and Yubdo Legebatu kebeles were selected from the area. Kebele is the lowest administrative unit within the district in Ethiopia. At the second stage, three villages were purposively select from each kebele. This is due to their high tendency to depend on non-timber forest resources from the forest reserve and proximity to forest. Therefore, twelve villages were selected for the study. The lists of households in each village were provided by Forest Cooperatives Executive Committee (ECs) and the kebeles leaders. Finally, simple random sampling was used to select households from selected village. Proportional sampling was used for sample size determination using formula proposed by Yamane (1967). Briefly, appropriate sample size was computed taking into consideration the projected number of households in the selected communities and representations of each community. The adoption of this formula was informed by the desire to draw a representative sample from the target population and also to minimize sampling error and bias.

The formula is express as:

$$
\mathbf{n}=\frac{\mathbf{N}}{\mathbf{1}+\mathbf{N}(\mathbf{e})^{2}}
$$

Where; $\mathrm{n}=$ is the sample size to be estimated, $\mathrm{N}=$ is population size, $\mathrm{e}=\mathrm{is}$ the level of precision $(0.05)$ and $\mathrm{N}=$ population size. Using the above formula, the computed sample size was 313 respondents. An existing household list per village was used to select households' heads to be interviewed randomly (Mbuvi et al., 2010). Accordingly, a total of 313 households were randomly selected from the list of households in the study area.

\subsection{Data collection}

Data were collected through personal interviews using a pretested structured questionnaire and focus group discussions (Dey et al., 2017b, 2017a; Raj et al., 2018; Suleiman et al., 2017). Moreover, key informants were also 
used for data collection. In each selected village, before starting the interview, a few days were devoted to establish rapport with the households. The questionnaires were pretested for elimination, addition, and alteration with nonsample respondents of the study area. After pretesting, final questionnaires were designed with both open- and close ended questions. The key respondents during the household survey were the household head as they are the decision makers for the households in the use of NTFPs. However, in the absence of the head of the family, the wife, eldest son, or the daughter was interviewed (Suleiman et al., 2017). The data collected include basic household variables, agricultural production, livestock, NTFPs extraction and off-farm activities. Along with information on income-generating activities, the personal information of each respondent interviewed has been gathered (e.g. household size, gender, age, wealthy, residence status (core versus buffer), and education level). The household information was collected through a face to face interview using a semi-structured questionnaire. A total of four FGDs were conducted, one in each selected kebeles. There were about 10 participants in the discussions which included the village leader, senior citizens of the village, some famous NTFP collectors and members of forest cooperatives executive committee (ECs). The information gathered from these discussions supplemented the household surveys which were finally used for interpretations of the results. Besides, twenty key informants (five for each kebeles) Forest Cooperatives Executive Committee (ECs), knowledgeable elders from forest users cooperatives, and development agent were selected through snowball sampling methods (Stepp, 2005). In this method, five (5) individuals were purposively asked to give the name of 5 KIs in each sample kebele, and then the most frequently appeared 5 KIs were taken for further discussion. Plant specimens listed by the participants were collected through walks in the forest with knowledgeable local people. The collected specimens were properly identified by comparing with already identified specimens in Herbarium of Ethiopian Biodiversity Institute using taxonomic literatures.

\subsection{Data analysis}

The data were analyzed using Microsoft Office Excel spreadsheet (2010) and SPSS version 20 software. A descriptive statistics was employed to analyze and summarize the data on reported non timber forest products and role of non timber forest product as income source. Data on the factors that influence respondents' income from NTFP was analyzed using linear regression.

\section{Result and Discussion}

\subsection{Socio-economic characteristics of sampled households}

The more than half $(60.1 \%)$ of the sample households were male, while the remaining $(39.9 \%)$ were female. Similar to this finding Fikir et al. (2016) found that the majority of the sample respondents (77\%) were male. Age distribution of respondents showed that the majority $(77.6 \%)$ of the sampled households were between the ages of 41-60 years (Table 1). This implies that majority of them are in their active age and are very nimble. This could be due to the fact that a lot of people of this age group would have taken it as their sources of income while some would have join them as a result of retirement. Moreover, this could probably have been influenced by being energetic, lack of formal employment, lack of basic entrepreneurship capital and NTFPs in the study area are regarded as common pool resources which can be accessed freely by any one. The results from this study also imply that most of the respondents are in their active age that can walk long distances and extract most of NTFPs to secure household food security, primary health care and cash income. Similar conclusion has been reached by Farinola et al. (2014) the $89 \%$ of the respondents were physically and economically active to engage in collection of NTFPs. About $29.4 \%$ of the respondents were illiterate, while the remainders were educated. Most of the NTFPs collectors in Chilimo forest have attained a primary education and are not employed by formal sectors. The majority were also involved in agriculture, NTFPs collection and trading during off seasons. This could be implying that collecting NTFPs in Chilimo is influenced by most of villagers who have attended formal education and lack employment in formal sector. Out of the sampled households married made up $84.7 \%, 9.3 \%$ widow and divorced $2.9 \%$, while only $3.2 \%$ of the samples households were single. This implies that NTFPs collectors in Chilimo were married thus NTFPs was important for sustaining households' income. Married households increase the size of the family which increases the demand of various resources. The finding of this study is in line with Ibrahim et al. (2018) that a high percentage of rural populations are married. They found that married people have the advantage of family labor than the unmarried.

Furthermore, the predominant household size was 6- 10 members $41.9 \%$ ) and the household sizes $1-5$ and $11-15$ were $32.9 \%$ and $25.2 \%$ respectively. With regards to farm size, the larger proportions of households $(41.5 \%)$ have 1-1.5ha, $0.5-1$ ha $(24.3 \%)$ and $1.6-2$ ha $(21.4 \%)$. Only, $12.8 \%$ of respondents have greater than 2 ha of land. From this result, it could be inferred that family labor would be readily available especially in gathering NFTPs around Chilimo forest. The finding of this study is in line with Ibrahim et al. (2018) that most of the household sizes were ranges between $6-10$ and which constitutes $48.33 \%$ of the respondents. They found that majority of those who extract NTFPs have relative big house hold size. This finding is also in line with Olaniyi et al. (2013) that many of the rural women $(69.2 \%)$ had between 6 and 10 members in their households. The average distance 
from home to Chilimo natural forest for the $55.6 \%$ households surveyed was $6-10 \mathrm{~km}$. About $44.4 \%$ travel $1-5 \mathrm{~km}$ to reach the natural forest and collect NTFPs from the forest.

Table 1: Socioeconomic characteristics of respondents Around Chilimo Natural forest, West Shewa, Ethiopia

\begin{tabular}{|c|c|c|c|}
\hline Variables & Categories & Frequency & Percentage \\
\hline \multicolumn{4}{|l|}{ Sex } \\
\hline & Female & 121 & 38.7 \\
\hline & Male & 192 & 61.3 \\
\hline \multicolumn{4}{|l|}{ Age } \\
\hline & $20-40$ & 88 & 28.12 \\
\hline & $41-60$ & 155 & 49.52 \\
\hline & $61-80$ & 52 & 16.61 \\
\hline & $>81$ & 18 & 5.75 \\
\hline \multirow[t]{4}{*}{ Education status } & Illiterate & 92 & 29.39 \\
\hline & $<4$ & 132 & 42.17 \\
\hline & $4-8$ & 84 & 26.84 \\
\hline & $8-12$ & 5 & 1.60 \\
\hline \multicolumn{4}{|l|}{ Marital status } \\
\hline & Single & 10 & 3.19 \\
\hline & Married & 265 & 84.66 \\
\hline & Widow & 29 & 9.27 \\
\hline & Divorced & 9 & 2.88 \\
\hline \multicolumn{4}{|l|}{ Family size } \\
\hline & $1-5$ & 103 & 32.91 \\
\hline & $6-10$ & 131 & 41.85 \\
\hline & $11-15$ & 79 & 25.24 \\
\hline \multirow[t]{3}{*}{ Wealthy status } & Rich & 68 & 21.73 \\
\hline & Medium & 136 & 43.45 \\
\hline & Poor & 109 & 34.82 \\
\hline \multirow[t]{4}{*}{ Land size } & $0.5-1$ ha & 76 & 24.28 \\
\hline & $1-1.5$ ha & 130 & 41.53 \\
\hline & 1.6-2ha & 67 & 21.41 \\
\hline & $>2 \mathrm{ha}$ & 40 & 12.78 \\
\hline
\end{tabular}

\subsection{Types of Non-Timber Forest Product and their income contribution}

3.2.1. Species used as NTFPs

In the present study, a total of 81 species belonging to 74 genera and 42 families were reported during the focus group discussion (Appendix 1). The most common families of plants mentioned were Lamiaceae, followed by Asteraceae and Fabaceae. Reshad et al. (2017) also reported that people in Jello-Muktar Forest, Eastern Ethiopia used nine NTFPs belonging to 97 plant species mainly for medicine, food, fodder and fuel wood which are comparable to main uses of NTFP in Chilimo Forest. NTFPs were distributed into different life forms, with tree having the most species followed by shrubs and herbs. This could be related with floristic composition of the vegetation of the area which is dominated by trees and shrubs. A high usage of perennials in our survey is also likely associated to the ability of trees and shrubs to withstand long dry seasons, which, in turn, help them, be widely available and abundant in semi-arid areas. Study done by Maua et al. (2018) also showed that the growth habits in South Nandi Forest, Kenya were led with Trees $(26.56 \%$. The most common NTFPs utilized in study area were firewood, fodder, charcoal and medicinal plants (herbs). The economically important parts of these NTFPs are mostly harvested by the local communities and sold as in unprocessed form. A similar situation of NTFP sale was also reported by Pandey et al. (2016) in which most NTFPs were free, and sold as raw materials. The main parts used for firewood were branches, followed by deadwood and stems. For grazing in the forest, grass, leaves and shrubs were the main parts eaten by livestock. Leaves, Roots, bark and seeds were the plant parts used for medicinal purposes.

\subsubsection{Types of Non-Timber Forest Products}

The NTFPs in Chilimo natural forest contributes largely to the well-being of the rural inhabitants. All interviewed households around Chilimo forest seem to extract variety of NTFPs throughout the year for their daily subsistence and income generation. Recently conducted study agrees on the fact that all interviewed households are engaged in the extraction of NTFPs (Heubach et al., 2011). The respondents reported that firewood, charcoal, grasses; medicinal, and honey were the major NTFP utilized in Chilimo area (Figure 2). Ninety eight percent of respondents reported that firewood contributed most to their annual income. This implies, the firewood is the major source of energy and income for forest fringe dwellers. The probable reason could be that fuel wood is the only available 
and affordable primary source of energy in this area. Moreover, fuel wood is sold in Ginchi town either directly to consumers or to the middlemen. According to the informants most households around Chilimo forest have no access to power from Ginchi town and they still use traditional three-stone stoves for cooking. This makes the use of firewood the most preferred choice by the locals of this study area. These open fire stoves normally consume huge amount of cooking biomass fuel which demand frequent access to forest to look for firewood. A study carried in Phnom Prich Wildlife Sanctuary, Cambodia revealed that $98 \%$ of informants collect fuel wood for energy source (Chou, 2017). Ariyo et al. (2018) stated that firewood recorded the highest quantity of 9,967 kg of rural households use as their main cooking fuel. In the case of study conducted at Yayo district, Western Ethiopia by Asfaw and Etefa (2017) firewood was recorded as main source (95.2\%) of energy. This is also in agreement with Ibrahim et al. (2016) that $89 \%$ of the informants used fuel wood daily as the primary source of energy for domestic purposes in New Bussa Nigeria.

About $75.8 \%$ of respondents reported that charcoal making contributed most to their annual income. This could probably be due to the reasons that charcoal is considered as cheap and easy to transport, distribute and store. Commercial charcoal production is encouraged by market condition in the study area as urban residents are the main user for charcoal in the study areas. Charcoal can be made all the year around, but production increases dramatically during dry season and famine time, although less of it is made during farming seasons. This is in line with the report of Ibrahim et al. (2016) that $64 \%$ of communities in Nigeria are using charcoal daily.

In the study area it was observed that $48.6 \%$ of respondents reported that they are collecting medicinal plants from the forest. The possible justification for this might be many ailments have also been detected and treated at family level (self-medicate) than always searching for modern medicine. Moreover, lack of poor accessibility of hospital and other health facilities in the study area results in different interaction between lay people and healers. At the same time, the need to cope daily with common mild diseases within the family of the villages promotes the acquisition and maintenance of some knowledge about medicinal plants and their uses. This was confirmed by Demie et al., (2018), who noted that most of the medicinal plants mainly obtained from the forest.

More than $69.2 \%$ of respondents said that grazing in the forest contributed most to their annual income. Some households' reported that grazing carried on specific days of the week such as weekends when labor for grazing was available from school going children. It was reported that all cattle types were be permitted in the forest to graze. In the study area, the cut and carry system is not common, except for a very few people who sell grass. The study also revealed that few $(6.7 \%)$ of respondents collected honey from the forest. The older people more engagement in the production of honey in the forest. Moreover, much of the honey is produced by use of the traditional log hives which have low quality and quantities compared to the modern bee hives. This practice is done by hanging the hives on trees and applying a certain herb to attract bees. It is a very laborious job and sometimes they need to stay the whole night for collection. This implies that collection of honey from the forest is low due to the fact that collection of honey is difficult activity which engages few of people. As reported during the interview, households delivered the raw honey to the nearby market, without product processing or any other value adding activity. A study by Chilalo and Wiersum in Southwest Ethiopia reported that honey production is stimulated by hanging traditional beehives in the forests. The findings from this study are higher than those reported by Olugbire et al. (2015) who conclude that a small proportion of rural population $(0.1 \%)$ engaged in the production of honey in the forest. 


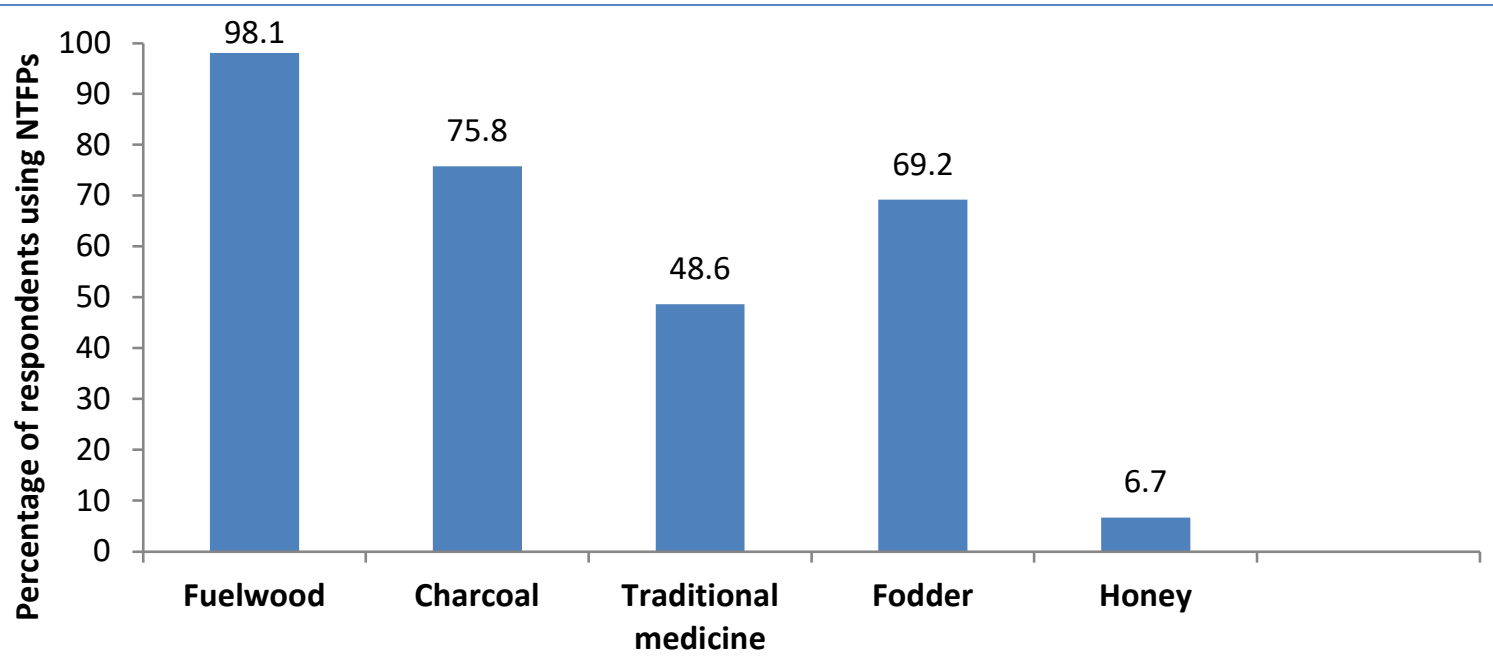

Types of Non timber Forest products

Figure 2. Proportion (\%) of respondents using different NTFPs around Chilimo forest, West Shewa, Ethiopia (n $=313$ ).

\subsubsection{Non-Timber Forest Product Income contribution}

The major livelihood strategies in the study area were farming (crop production and livestock), NTFPs collection and non-farm activities. As shown in the table 2, income from agriculture was the major and highest income sources $(61.23 \%)$ share to the total household income for local people residing around Chilimo forest. Similar conclusion have been reached by Dash et al. (2016) that agriculture considered as main source of livelihood for local people residing in and around Similipal Tiger Reserve of India.

With an average income share of $29.34 \%$ income from NTFPs accounted for the second largest share in total household income, next to crop production (39.1\%). This result suggests that NTFPs contribute significantly to household income and thus can act as a safety net during the period of hardship and other emergencies. This finding also implies that NTFPs constitutes an important component of the rural households' economy as they account for one-third of the total households' income in the study area. The results indicated that households involved in NTFPs collection (29.34\%) is higher when compared to Reshad et al. (2017) and Meles et al. (2016) where the share of NTFP income to be $10.11 \%$ and $1.3 \%$ respectively. A study made by Melaku et al. (2014) in Bonga forest area, southwestern Ethiopia estimated that NTFPs income is the second most important source of household income, contributing about $47 \%$ of the total household income. This finding also agrees with studies conducted in Kano, Nigeria by Suleiman et al.( 2017) where NTFPs contributing about 30\% of the total annual household income as compared to crop production. This result agreed with a previous report that a large proportion of rural population earn their livelihoods from the collection or extraction and sales of NFTPs thereby improving the quality of life and standard of rural population living around forestlands (Aiyeloja et al., 2012). The previous study also revealed that collection and processing of NTFPs provide major employment opportunity to the rural dwellers (Oyun, 2009).

In contrast, the low contribution of off-farm incomes $(9.43 \%)$ to the total household incomes documented in this study showed that off-farm activities are low-income generating practices.

Table 2: Mean annual household cash income (Birr/year and relative contribution) in livelihood improvement around Chilimo forest, West Shewa, Ethiopia

\begin{tabular}{llll}
\hline Source of income & Mean Income per year(Birr/Year/household) & Std. Deviation & $\begin{array}{l}\text { Income } \\
\text { share \% }\end{array}$ \\
\hline Farm income & 51219.17 & 3982.022 & 61.23 \\
Non-farm income & 804.18 & 518.37 & 9.43 \\
NTFP income & 2501.1 & 2220.27 & 29.34 \\
\hline
\end{tabular}

\subsection{Determinants of NTFPs income}

Table 3 shows the results of linear regression analysis regarding socio-economic factors determining income from NTFPs. The regression showed that the model was significant at the $5 \%$ probability level (Table 3 ). $\mathrm{R}^{2}$ of 0.460 indicated the explanatory power of the model. Thus, $46 \%$ of the variation in the dependent variables was explained by the regression. Among the various characteristics considered gender, family size and wealth status of the households have positive and significant relationships on income derived from NTFPs (Table 3). But, total land holding was negatively and significantly correlated with income derived from NTFPs (Table 3). 
The study showed that the coefficient associated with gender had a positive and statistically significant impact on respondents' income from NTFP (Table 3). This implies, men were the dominant extractors of NTFPs than women. The probable reason could be that the large percent of NTFPs were sourced from dense forest where women might not be secure enough to go and collect from long distances and hilly area. NTFPs collection activities in natural forest need active individuals and are illegal, time-consuming and tedious, women are discouraged from the risky practices compared with men who are more willing to take risks of violating the rules governing extraction of NTFPs in the Chilimo forest. Furthermore, cultural norms in most communities of Western Ethiopia restrict women from engaging in outdoor activities such as collection of non timber forest products. Most of the collectors of fuel wood, charcoal, fodder and honey from natural forest were men. However, few of the women were engaged in the collection of herbal medicine and fuel wood from nearby forest and home garden. This implies that NTFPs extraction is male dominated activity in the study area. This result is inline study done by Opaluwa et al. (2011) in North Central, Nigeria who reported that gender is the factor that affects the collection of NTFPs.

The findings also indicated that family size is positively related to households' income from NTFPs and its impact is found to be significant, suggesting that the larger family sizes are prone to have more labor available to support households' NTFPs extractions from nearby forestlands (Table 3). The implication of this result could be that increase in family size means that the population is gradually growing has a direct correlation with the collection of non timber forest products for subsistence and income generation. Large families are also more likely to face lower per capita land availability and high dependency ratios for food requirements. They may thus rely on forest resources around them because of the available family labor that can be utilized for NTFPs collection. Similar conclusion have been reached by Suleiman et al. (2017) who reported that families with large households who lived adjacent to forestlands in Kano, Nigeria derived more resources from the common resources due to labor availability. This finding is also line with Fikir et al. (2016). Moe and Liu (2016) also found that household size was positively correlated with NTFPs income. They found that household with larger number of working people may tend to involve more in the NTFPs collections.

In this study, the coefficient associated with the respondents' wealthy status had a positive and statistically significant impact on respondents' income from NTFP (Table 3). This implies the rich household generates more cash income than the middle and the poor. A possible reason may be that poor households have few asset bases and mostly depend on NTFPs extraction and use to sustain their livelihoods than other household income categories. Most of them rely on forest mainly NTFPs as a source of income and subsistence since they lack alternative means of source of income. Study done in Setit Humera, Western Tigray of Ethiopia also indicated poor wealth group depends more on NTFPs than medium and rich wealth group due to the fact that poor households have few income to sustain their livelihood (Meles et al., 2016). Thus, the poor seems depend more on NTFPs for income generation.

The study also revealed that, land size has a negative and statistically significant effect on income from NTFP (Table 3). This implies land-poor households are more likely to collect NTFPs from the forest in order to increase their households' incomes and other basic needs. Those land-poor families in study area were not able to produce enough agricultural products for their households and income needs, hence, largely depend on the forest products to complement their livelihoods. Moreover, land possession in Ethiopia increases the economic potential and the ability to have adequate space for rising own NTFPs, for instance, grazing land and a woodlot to provide various products particularly firewood which is a major source of cooking energy in the area. Thus, households with more income from agriculture and livestock were less dependent on NTFPs resources. This finding is similar to Asfaw and Etefa (2017) who concluded that households with small size of land are more likely to be a collector of forest products. This result is also in line with the finding of Illukpitiya \& Yanagida (2008) who stated that forest dependency decreased for households with more diversified income sources and sources of diversify household income include agriculture and livelihood production. Similar findings have been reported in South Nandi Forest of Kenya, by Maua et al. (2018) who found out that dependence on forest was strongly correlated with the size of landholdings, with the landless being the most dependent. Moreover, Moe and Liu (2016) found that total land holding showed positive relation to income derived from NTFPs. But this result is opposite to the findings of Angelsen et al. (2014). 
Table 3. Regression analysis of household annual NTFPs income Vs socioeconomic characteristics

\begin{tabular}{llllll}
\hline Variables & $\mathrm{B}$ & Std. Error & Beta & $\mathrm{t}$ & Sig. \\
\hline \hline Respondent sex & 638.237 & 204.088 & 0.141 & 3.127 & $0.002 *$ \\
Respondent age & 170.570 & 123.420 & 0.063 & 1.382 & 0.168 \\
Education level & -18.305 & 121.699 & -0.007 & -0.150 & 0.881 \\
Marital status & 179.866 & 201.727 & 0.039 & 0.892 & 0.373 \\
Family size & 1130.375 & 167.987 & 0.387 & 6.729 & $0.000^{*}$ \\
Distance from forest & -323.393 & 193.731 & -0.072 & -1.669 & 0.096 \\
Respondent's wealth status & 434.694 & 153.244 & 0.145 & 2.837 & $0.005^{*}$ \\
Total land holding in ha & -477.073 & 122.566 & -0.206 & -3.892 & $0.000^{*}$ \\
\hline
\end{tabular}

Dependent Variable: Non timber forest product income, F:31.651, P (.000), Adjusted R ${ }^{2}(0.460)$, Significant Level: $* P<0.05$

\subsection{The Contribution of NTFPs Collection to Forest Conservation}

Increased income from NTFPs provide stimulus for local communities to protect their forest and manage sustainably. In the present study, many NTFPs can be harvested without significantly changing the forest, hence maintaining the forest environmental services and biological diversity. The plant parts with highest utilization are dead stem and branches, followed by leaves. Harvesting of these products, especially dead branches have less impact on the species at individual and population level, provided correct harvesting method is employed and other parts of the plant are not damaged during dead stem harvest. Comparing to that of logging and conversion of land to other land use harvesting of NTFPs have minimum ecological impact. Moreover, participatory forest management in Chilimo forest has been raised seedlings for enriching replanting programs. These seedlings are both indigenous and exotic species have helped to treat previously degraded forests. The protection of the forests by the users, and the rights of ownership has greatly reduced the incidence of forest fires and enhance sense of ownership.

Many of the trees providing NTFPs are the long-lived trees, so all parts of the trees play a role in carbon sequestration. The carbon storage function has the social value which equals to the social damage avoided by not releasing the $\mathrm{CO} 2$ into the atmosphere. The forest can reduce flood volumes during heavy rainfall, and in dry seasons, forest gradually releases the absorbed water that maintains river flow. Moreover, the forest helps to prevent soil erosion and minimize sedimentation in water reservoir or rivers. This finding is consistent with other studies that NTFPs play a direct or indirect role to maintain the value of ecosystem services because extraction activities do not impact critically to the forest or trees (Ros-Tonen and Wiersum, 2005).

\section{Conclusions}

The livelihood activities of households in the study area consist of crop production, livestock husbandry, harvesting of NTFPs and off-farm activities. Within such diversified income sources, NTFPs plays an important role in improving the livelihood of local community. The majority of households engaged in NTFPs collection for subsistence and commercial purpose. The most common NTFPs utilized in area were firewood, charcoal, grasses; medicinal plants and honey which accounted $29.34 \%$ of annual household income. Furthermore, the current study highlighted that gender; family size and wealth status have significant influence on income derived from the collection of NTFPs, whereas age, education, marital status and distance from forest were found to have no significance association with income sourced from the harvesting of NTFPs. This study also reveals that enrichment planting of the most utilized tree species, participatory forest management and setting of harvesting levels and cycles in Chilimo forest reduce impacts on plant species that are in high demand by local communities. The results suggest that a shift from primarily subsistence to a more of cash economy may lead to unsustainable exploitation of NTFP and subsequent biodiversity loss.

\section{Acknowledgments}

We are very grateful to Ambo University for providing us field materials. We would also like to extend our gratitude to the Ambo University for fully funding the study and allowing us use facilities to identify plant specimens. We would also like to extend our gratitude to the Ethiopian Biodiversity Institute for allowing us use facilities to identify plant specimens. The acknowledgement should also go to Chilimo informants who unreservedly shared their knowledge with us.

\section{Authors' contributions}

Gadisa Demie is a lecturer at Department of Forestry, College of Agriculture and Veterinary Science Ambo University. He planned the study, collected data, identified the species, analyzed the data and writes the manuscript. 


\section{Reference}

Agrawal. A. and Ostrom, E. (2001). Collective action, property rights, and decentralization in resource use in India and Nepal. J Polit Soc. 29, 485-514.

Aiyeloja, AA., Oladele. AT. And Ezeugo, O.E. (2012). Evaluation of non timber forest products trade In Ihiala local government area, Anambra State, Nigeria. International Journal of Science and Nature. 3 (2), 366-372.

Aiyeloja, AA., Ajewole, O.I. (2006). Non-timber Forest Products' Marketing in Nigeria: A case study of Osun State. Educational Research and Reviews.1 (2), 52-58.

Alden, WL. (2011). The Law is to blame: The vulnerable status of common property rights in Sub-Saharan Africa. Dev and Chan. 42,733-757.

Alemayehu, NA., Wiersum, KF. (2006). Community perspective on participatory forest management. The case of Chilimo participatory forest management scheme in Ethiopia. Ethi J Nat Resou. 8,57-75.

Angelsen, A., Jagger, P., Babigumira, R., Belcher, B., Hogarthm, NJ., Bauch, S., Wunder, S. (2014). Environmental income and rural livelihoods: A global comparative analysis. World Development, 64, 12-28. doi:10.1016/j.worlddev.2014.03.006

Ariyo, OC., Adedokun, MO., Ariyo, MO. (2018). Determinants of the Quantity of Non-timber Forest Products Collected from Forests of the International Institute of Tropical Agriculture in Ibadan, Nigeria. AJRAF. 1(1), $1-13$.

Arts, B., Buizerm, M. (2009). Forests, discourses, institutions: a discursive-institutional analysis of global forest governance. J Forest Poli Econ. 11, 340-347.

Asfaw, A., Etefa, L.(2017). The contribution of Non-Timber Forest Products to the Rural Livelihood:The case of Yayo district, illu ababora zone, oromia regional state, western Ethiopia. International Journal of Applied Agricultural Research. 12(2),157-169.

Bwalya, S M. (2013). Household Dependence on Forest Income in Rural Zambia,” Zambia Soc. J. 2, 1.

Chilalo, M., Wiersum, KF. (2011). The role of non-timber forest products for livelihood diversification in Southwest Ethiopia. Ee-JRIF. 3(1), 44-59.

Chou., P. (2017). The Importance of Non-timber Forest Products in Rural Livelihoods and Ecosystem Services at Phnom Prich Wildlife Sanctuary, Cambodia. IJERD. 8-1.

CIFOR. (2011). Forests and non-timber forest products. CIFOR fact sheets. http://www.cifor.cgiar.org/publications/corporate/factSheet/NTFP.htm, retrieved on 13 September 2011.

Dash, M., Behera, B., Rahut, DB. (2016). Determinants of household collection of non-timber forest products (NTFPs) and alternative livelihood activities in Similipal Tiger Reserve, India. Forest Policy and Economics. 73, 215-228.

Demie, G., Negash, M., Awas, T. (2018). Ethnobotanical study of Medicinal plants used by indigenous people in and around Dirre Sheikh Hussein heritage site of South-eastern Ethiopia Journal of Ethnopharmacology. 220, 87-93.

Dey T, Pala NA, Shukla G, Pal PK, Chakravarty S (2017b). Perception on impact of climate change on forest ecosystem in protected area of West Bengal, India. Journal of Forest and Environmental Science, 33, 1-7. doi:10.7747/JFES.2017.33.1.1

Dey T, Pala NA, Shukla G, Pal PK, Das G, Chakravarty S (2017a). Climate change perceptions and response strategies of forest fringe communities in Indian Eastern Himalaya. Environment, Development and Sustainability. doi:10.1007/s10668-017-9920-1

Endamana, D., Angu, KA., Akwah, GN., Shepherd, G., Ntumwe, BC. (2016). Contribution of non-timber forest products to cash and non-cash income of remote forest communities in Central Africa. International Forestry Review, 20, 1-16.

Endamana, D., Angu, KA., Akwah, GN., Shepherd, G., Ntumwel, BC. (2016). Contribution of non-timber forest products to cash and non-cash income of remote forest communities in Central Africa. Int For Rev. 18(3),280295.

FAO. (2008). An Information Bulletin on Non-Wood Forest Products: Non-Wood News. Food and Agriculture Organisation of the United Nations Rome 17:12-21.

FAO. (1996). Domestication and Commercialization of Non-Timber Forest Product. Agroforestry System, 9:3239

FAO. (2012). State of the World's Forests 2012. FAO, Rome, http://www.fao.org/3/ a-i3010e.pdf. Accessed July 2015.

Farinola, LA., Famuyide, OO., Nosiru, MO., Ogunsola, AJ. (2014). Survey of Identified Non Timber Forest Products and Their Role in the Rural Livelihood of Inhabitants of Omo Forest Reserve, Ogun State. International Journal of Agriculture and Forestry, 4(4), 317-324.

Fikir, D., Tadesse, W., Gure, A. (2016). Economic Contribution to Local Livelihoods and Households Dependency on Dry Land Forest Products in Hammer District, Southeastern Ethiopia. International Journal of Forestry Research. Article ID 5474680, 11 pages http://dx.doi.org/10.1155/2016/5474680 
Food and Agriccultural Organisation. (2011). Economic and social significance of forests for Africa's sustainable development. Nature and Faune http://www.fao.org/docrep/014/am723e/am723e00.pdf

Gardei, S. (2006).Local valuation of forests in South West Ethiopia. Non timber Forest Products Research and Development Project in SW Ethiopia, Wageningen,Student research Series No. 6. Netherlands.

Heubach, K., Wittig, R., Nuppenau, EA., Hahn, K.(2011). The economic importance of non-timber forest products (NTFPs) for livelihood maintenance of rural West African communities: A case study from northern Benin. Ecological Economics. 70, 1991-2001.

Ibrahim, AO., Ampitan, TA., Adeniji, OA., Olayinka, AP., Babatunde, KO. (2016). Utilization of Non-Timber Forest Products (NTFPs) in New Bussa, Nigeria International Journal of Research in Agriculture and Forestry. 3(10), 17.

Ibrahim, Y., Aminu, SA., Kumar, H. (2018). Contribution of non-timber forest products to rural household income and livelihood security in Jakusko local government area of Yobe state, Nigeria. Journal of Pharmacognosy and Phytochemistry. 7(6), 509-513.

Illukpitiy, AP., Yanagida, JF. (2008). Role of income diversification in protecting natural forests: evidence from rural households in forest margins of Siri Lanka. Agroforest Syst 74,51-62, DOI 10.1007/s10457-008-91532 .

Mahaptara, A., Mitchell, CP. (2011). Non-timber Forest Products Management Problems and Prospects: A case study from India. Retrieved on 8th June 2011 from http://www.w3c.org/TR/1999/REC-html40119991224/loose.dtd.

Maua, JO., Mugastia Harrison, T., Joshua, C. (2018). Species Diversity and Utilization of Non-Timber Forest Products (NTFPs) by Households Adjacent to South Nandi Forest, Kenya. Journal of Natural Sciences Research.8,20.

Mbuvi, MTE., Gichuki, J., Musyoki, JK. (2010). Socio-economic report for South Nandi forest Adjacent Communities. Nature Kenya - Kenya Forestry Research Institute publication.

Melaku, E., Ewnetu, Z., Teketay, D. (2014). Non-timber forest products and household incomes in Bonga forest area, southwestern Ethiopia. Journal of Forestry Research 25(1), 215-223.

Meles, B., Bekele, T., Tadese, S. (2016). Role of non timber forest products to livelihoods of rural households: Setit Humera, Western Tigray, Ethiopia. wjpls, 2 (4), 33-48.

Moe, KT., Liu1, J. (2016). Economic Contribution of Non-timber Forest Products (NTFPs) to Rural Livelihoods in the Tharawady District of Myanmar. International journal of scienece.5, 01.

Mulenga, BP., Richardson, RB., Mapemba, LD., Tembo, G. (2011). The contribution of non-timber forest products to rural household income in Zambia (No. 109887). Michigan State University, Department of Agricultural, Food, and Resource Economics. Available at:https://ideas.repec.org/p/ags/midcwp/109887.html

Ojea, E., Loureiro, M L., Allo M., Barrio, M. (2016). Ecosystem services and REDD: Estimating the benefits of non-carbon services in worldwide forests. World Development, 78, $246-261$. doi:10.1016/j.worlddev.2015.10.002

Olaniyi, OA., Akintonde, JO., Adetumbi, SI. (2013). Contribution of Non-Timber Forest Products to Household Food Security among Rural Women in Iseyin Local Government Area of Oyo State, Nigeria. Research on Humanities and Social Sciences 3, 7.

Olugbire, OO., Ayomide, AA., Aremu, FJ. (2015). Socio-Economic Analysis of Non-Timber Forest Products Activities and Income among Rural Households in Nigeria. Elixir Agriculture. 84,34030-34032.

Opaluwa, HI., Onuche, U., Sale, FA. (2011). Factors Affecting the Collection and Utilization of Non- Timber Forest Products in Rural Communities of North Central, Nigeria. J. Agric. Food. Tech. 1(5), 47-49.

Oyun, M.B. (2009). The Role of Non-timber Forest Products on the Livelihoods of Fringe Communities of Idanre Forest Reserve, Nigeria. Forests and Forest Products Journal. 2, 62-75.

Pandey, AK., Bhargava, P., Negi, MS. (2011). Sustainable management of non-timber forest produce through joint forest management. Indian Forester, 137, 105-113.

Pandey, AK., Tripathi, YC., Kumar, A. (2016). Non timber forest products (NTFPs) for sustained livelihood: Challenges and strategies. Research Journal of Forestry,10(1), 1-7.

Raj, AJ., Biswakarma, S., Pala, NA., Shukla, GV., Kumar, M., Bussman, RW. (2018). Indigenous uses of ethnomedicinal plants among forest-dependent communities of northern Bengal, India. Journal of Ethnobiology and Ethnomedicine, 14, 8. doi:10.1186/s13002-018-0208-9

Reshad, M., Mohammed, M., Mohammed, A., Beyene, A. (2017). Socio-Economic Importance of Non-Timber Forest Products and Its Implication on Natural Forest Conservation: The Case of Jello-Muktar Forest, Southeastern Ethiopia. Journal of Economics and Sustainable Development.8,17.

Ros-Tonen, MAF., Wiersum, KF. (20050. The scope of improving rural livelihoods through non-timber forest products, An evolving research agenda. People, Trees and Livelihoods.15 (2), 129-148.

Stepp, JR. (2005). Advances in Ethno biological field methods. Field Methods. 17, 211-218. 
Suleiman, MS., Wasonga, VO., Mbau, JS., Suleiman, A., Elhadi, YA. (2017). Non-timber forest products and their contribution to household's income around Falgore Game Reserve in Kano, Nigeria. Ecological Processes, 6 , 23. doi:10.1186/s13717-017-0090-8

Tsingalia, JOM., Harrison, M., Joshua, C. (2018). Socioeconomic Factors Influencing Dependence of Households on Non-Timber Forest Products in South Nandi Forest, Kenya. Journal of Economics and Sustainable. ISSN 2222-1700 (Paper) ISSN 2222-2855 (Online) Vol.9, No.14.

Worku M (2014). Traditional uses of non-timber forest products in southwest Ethiopia: Opportunities and challenges for sustainable forest management. Journal of Agriculture and Environmental Sciences.1(1).

Wunder, S., Angelsen, A., Belcher, B. (2014). Forests, livelihoods and conservation: Broadening the empirical base. World Development, 64, 1-11. doi:10.1016/j.worlddev.2014.03.007

Yamane. (1967). Determining Sample Size. University of Florida, USA .

Appendix 1: Species listed during FGD by informants with their family name Around Chilimo Forest, West Shewa, Ethiopia

\begin{tabular}{|c|c|c|}
\hline No & Botanical name & Family \\
\hline 1 & Acacia abyssinica Hochst ex Benth. & Fabaceae \\
\hline 2 & Acokanthera schimperi A.DC.) Schweinf & Apocynaceae \\
\hline 3 & Agave sisalana Perro ex Eng. & Agavaceae \\
\hline 4 & Albizia schimperiana Oliv. & Fabaceae \\
\hline 5 & Artemisia abyssinica Sch. Bip. ex A. Rich. & Asteraceae \\
\hline 6 & Arundinaria alpina K.Scum. & Poaceae \\
\hline 7 & Asparagus africanus Lam & Asparagaceae \\
\hline 8 & Bersama abyssinica Fresen. & Melianthaceae \\
\hline 9 & Bothriocline schimperi Oliv.\& Hiern ex Benth & Asteraceae \\
\hline 10 & Bridelia micrantha (Hochst.) Baill. & Euphorbieaceae \\
\hline 11 & Brucea antidysenterica J.F.Mill. & Simaroubaceae \\
\hline 12 & Buddleja polystachya Fresen. & Loganiaceae \\
\hline 13 & Calpurnia aurea (Ait.)Benth. & Fabaceae \\
\hline 14 & Carduus schimperi Sch. Bip & Asteraceae \\
\hline 15 & Carissa spinarum L. & Apocynaceae \\
\hline 16 & Celtis africana Burm. f. & Ulmaceae \\
\hline 17 & Clausena anisata (Willd.)Benth & Rutaceae \\
\hline 18 & Clerodendrum myricoides (Hochst.) Vatke & Lamiaceae \\
\hline 19 & Clutia abyssinica Jaub. \& Spach. & Euphorbiaceae \\
\hline 20 & Commiphora africana (A. Rich) Engl. & Burseraceae \\
\hline 21 & Cordia africana Lam. & Boraginaceae \\
\hline 22 & Croton macrostachyus Del. & Euphorbiaceae \\
\hline 23 & Cupressus lusitanica Mill. & Cupressaceae \\
\hline 24 & Dodonaea angustifolia & Sapindaceae \\
\hline 25 & Dolichos sericeus & Fabaceae \\
\hline 26 & Dombeya torrida (J. F. Gmel.) P. Bamps & Sterculiaceae \\
\hline 27 & Dovyalis abyssinica (A.Rich.) Warp & Flacourtiaceae \\
\hline 28 & Dovyalis verrucosa (Hochat.) Warb. & Flacourtiaceae \\
\hline 29 & Echinops kebericho Mesfin & Asteraceae \\
\hline 30 & Ehertia cymosa Thonn & Boraginaceae \\
\hline 31 & Ekebergia capensis Sparrm. & Meliaceae \\
\hline 32 & Embelia schimperi Vatke & Myrisinaceae \\
\hline 33 & Eucalyptus globulus Labill. & Myrtaceae \\
\hline 34 & Ficus sur Forssk. & Moraceae \\
\hline 35 & Ficus sycomorus L. & Moraceae \\
\hline 36 & Ficus thinningii Blume & Moraceae \\
\hline 37 & Ficus vasta Forssk. & Moraceae \\
\hline 38 & Gnidia glauca (Fresen.) Gilg & Thymelaeaceae \\
\hline 39 & Grewia ferruginea Hochst. ex A. Rich. & Tiliaceae \\
\hline 40 & Hagenia abyssinica (Bruce) I.F. Gmel & Rosaceae \\
\hline 41 & Hypericum revolutum Vahl & Hypericaceae \\
\hline 42 & Jasminum abyssinicum Hochst. ex A.Rich. & Oleaceae \\
\hline 43 & Juniperus procera Endl. & Cupressaceae \\
\hline 44 & Justicia schimperiana (Hochst. ex Nees) T Anders. & Achanthaceae \\
\hline
\end{tabular}




\begin{tabular}{|c|c|c|}
\hline No & Botanical name & Family \\
\hline 45 & Landolphia buchananii (Hall.f.) Stapf & Apocynaceae \\
\hline 46 & Lepidotrichilia volkensii (Giirke) Leroy & Meliaceae \\
\hline 47 & Lippia adoenesis Hochst. ex Walp. & Verbenaceae \\
\hline 48 & Maesa lanceolata Forssk. & Myrsinaceae \\
\hline 49 & Maytenus addat (Loes.) & Celasteraceae \\
\hline 50 & Maytenus arbutifolia (A.Rich.) Wilczek & Celasteraceae \\
\hline 51 & Myrsine africana $\mathrm{L}$. & Myrsinaceae \\
\hline 52 & Myrsine melanophloeos (L.)R.Br. & Myrisinaceae \\
\hline 53 & Nuxia congesta R.Br. ex Fresen & Loganiaceae \\
\hline 54 & Ocimum lamiifolium $\mathrm{L}$. & Lamiaceae \\
\hline 55 & Ocimum urticifolium Roth & Lamiaceae \\
\hline 56 & Olea capensis L. supsp. macrocarpa (C. H. Wright) Verdc. & Oleaceae \\
\hline 57 & Olinia rochetiana A.Juss. & Oliniaceae \\
\hline 58 & Osyris quadripartita Decn. & Santalaceae \\
\hline 59 & Otostegia integrifoliaBenth. & Lamiaceae \\
\hline 60 & Pavonia urens Cav. & Malvaceae \\
\hline 61 & Phoenix reclinata Jacq. & Arecaceae \\
\hline 62 & Phytolacca dodecandra L'Herit. & Phytolaccaceae \\
\hline 63 & Premnaschimperi Engl. & Lamiaceae \\
\hline 64 & Prunus africana (Hook.f.)Kalkm. & Rosaceae \\
\hline 65 & Rhamnus prinoides L'herit. & Rhamnaceae \\
\hline 66 & Ritchiea albersii Gilg & Caparidaceae \\
\hline 67 & Rosa abyssinica Lindley & Rosaceae \\
\hline 68 & Rumex nervosus Vahl & Polygonaceae \\
\hline 69 & Salix mucronata Thunb & Salicaceae \\
\hline 70 & Salix subserrataWilld. & Salicaceae \\
\hline 71 & Satureja punctata (Benth.) Briq. & Lamiaceae \\
\hline 72 & Schefflera abysinica (Hochst. ex A. Rich.) Harms & Araliaceae \\
\hline 73 & Scolopia theifolia Gilg & Flacourtiaceae \\
\hline 74 & Syzygium guineense (Willd.) DC. Subsp afromontanum & Myrtaceae \\
\hline 75 & Tamarindus indica $\mathrm{L}$ & Fabaceae \\
\hline 76 & Teclea nobilis Del. & Rutaceae \\
\hline 77 & Urera hypselodendron (A.Rich.)Wedd. & Urticaceae \\
\hline 78 & Urtica simensis Steudel & Urticaceae \\
\hline 79 & Vernonia amygdalina Del. & Asteraceae \\
\hline 80 & Ziziphus mucronata Willd. & Rhamnaceae \\
\hline 81 & Ziziphus spina-christi L. & Rhamnaceae \\
\hline
\end{tabular}

